\title{
"Camarão que dorme a onda leva": ponderações éticas sobre o trabalho de campo em contextos perigosos
}

\author{
MAYCON LOPES \\ Universidade Federal da Bahia, Salvador, Bahia, Brasil
}

DOI 10.11606/issn.2316-9133.v26i26p386-408

resumo A partir do relato de uma situação extrema - de violência e ameaça direta à vida - experimentada no curso de uma etnografia, pretendo neste texto abordar questões metodológicas e éticas mais amplas inerentes à dinâmica do trabalho de campo. Exploro, entre outros pontos, a introdução (neste caso, indevida) de dispositivos fotográficos durante a observação participante e os desdobramentos do episódio na produção dos dados e na conformação da investigação de modo geral. Argumento que diante da violência que permeia a cidade contemporânea, e a que necessariamente - com níveis de risco variados os estudiosos estão expostos nas chamadas pesquisas in loco em contextos marcados pela criminalidade (como favelas dominadas pelo tráfico de drogas), é fundamental discutirmos medidas que possam vir ao auxílio dos mesmos, seja para não comprometer a realização do estudo, seja, principalmente, para salvaguardar sua integridade física e psíquica.

palavras-chave ética de pesquisa; trabalho de campo; etnografia; periferia; fotografia.

"Camarão que dorme a onda leva": ethical ponderations regarding the fieldwork in dangerous contexts

abstract Based on the retelling of an extreme situation - of violence and direct threat to life - experienced in the course of fieldwork, in this text, I wish to deal with broader methodological and ethical questions inherent in the dynamics of fieldwork. I investigate among other points, the introduction (unwarranted, in this case) of photographic devices during the participant observation and the consequences of this episode in the findings and in the formation of the investigation in general. I argue that given the violence that permeates the modern city, and to which necessarily, with variable risk levels, researchers are exposed in the so called research in loco in contexts characterized by criminality (such as slums dominated by the drug trade), it is fundamental to consider strategies that could be of 
assistance, be they so as not to compromise the realization of the study, or primarily to safeguard their physical and psychological integrity.

keywords research ethics; fieldwork; ethnography; urban periphery; photography.

\section{Risco e controle no fazer etnográfico, uma breve introdução}

Usualmente nos programas de metodologia científica põe-se demasiada ênfase no controle da pesquisa. Entretanto, quando se lança mão de uma abordagem etnográfica, cuja premissa consiste em estar disponível, em seguir os outros por onde quer que nos possam levar (INGOLD, 2016), terminamos por abrir o expediente da pesquisa, por vezes de modo radical, à contingência e ao inesperado. Se é verdade que para o antropólogo, como comenta Goldman (2006) em referência a Clifford Geertz, a socialidade constitui não apenas objeto como o único meio de pesquisa disponível - e por isso estudamos as experiências humanas a partir de uma experiência pessoal -, nos aventurar no mundo com as pessoas fazendo mais que entrevistá-las, participar de suas vidas cotidianas, é mais que um chamado; trata-se de um imperativo da observação participante, uma "obrigação metodológica" por assim dizer (BOURGOIS, 1990; NILAN, 2002).

Essa encorajadora tradição da antropologia ${ }^{1}$, a observação participante, seu método por excelência, impõe certos desafios ao controle do pesquisador. Quando não, no limite, o opõe a imprevisibilidade. Franqueado, negociado, reclamando improvisações e criatividade, o controle do pesquisador ${ }^{2}$ pode ser perdido, tornando o corpo-sujeito-pesquisador vulnerável diante de adversidades do percurso da investigação. O interesse aqui, porém, não é discutir essas questões a nível genérico e abstrato, mas apresentar - aliás, não sem assumir responsabilidade sobre o episódio - um testemunho em primeira pessoa de uma situação de campo em que minha própria agência e autonomia na condição de pesquisador foi implacavelmente posta em xeque. Nem tudo em uma pesquisa, afinal, é totalmente negociável; o perigo é um desses imponderáveis.

\footnotetext{
${ }^{1}$ Embora não se excluam ou sejam inconciliáveis, frequentemente os métodos qualitativos em ciências sociais podem, grosso modo, ser divididos em duas abordagens, conforme aponta Nilan (2002): aquelas mais formais (entrevista, grupo focal) e as etnográficas (trabalho de campo, observação participante). Se na primeira põemse em relevo o controle, a objetividade, o distanciamento e até mesmo o desapego emocional, a segunda é marcada pelo paradigma da imersão, do envolvimento, da reflexividade e do relacionamento. Produz-se, a depender da abordagem adotada, posições diversas do sujeito-pesquisador. Se a primeira pode ser mais confortável para este sujeito, a segunda, do pesquisador imerso - conclui Nilan- é mais comumente aberta às possibilidades de risco e perigo. A abordagem é encorajadora porque, a despeito do menor controle e da maior vulnerabilidade emocional, entende-se que promete dados mais ricos e interessantes.

${ }^{2}$ Esse controle nunca está em posse exclusiva do pesquisador ou supervisor da pesquisa, mas distribuído e mediado (quando aplicáveis) pelos comitês de ética, agências de fomento, orientadores, etc., a começar pelos prazos estabelecidos.
} 
Qual Sluka (2007), assumo como pressuposto que o pesquisador não está disposto senão metaforicamente, ressalvo - a dar a vida por seu estudo. Como se verá, não é exagero ou capricho dizer que se trata de uma questão de vida ou morte (SLUKA, 2007). Até por ser fato que o mundo não tem se tornado um lugar mais tranquilo (SLUKA, 2007), estou convencido quando argumentam em favor da promoção do perigo a uma questão, um problema metodológico bastante prático: como enfrentar a crise, a violência ou o terror no trabalho de campo (BOURGOIS, 1990; SLUKA, 2007), a começar pela identificação das ameaças ao curso da pesquisa (GAMA; PEIXOTO, 2017, p. 188). De acordo com Bourgois (1990), em geral as estratégias de sobrevivência só são pensadas quando os pesquisadores já se encontram lá, diante de uma situação de hostilidade, e não nos programas de pósgraduação que os formam.

Questão que parece não estar recebendo a devida atenção da antropologia, sobretudo em tempos em que se multiplicam os olhos com os quais enxergamos, abordo a introdução da fotografia no trabalho de campo. Isto porque, com a propagação dos smartphones, que permitem que a produção de fotografias seja incorporada de modo sem precedentes ao cotidiano, estamos frequentemente munidos de dispositivos fotográficos quando em campo. O próprio aparelho específico de gravação de voz tornou-se um tanto anacrônico, uma vez que os smartphones, que têm na versatilidade e na portabilidade suas principais características (JANSSON, 2014), reúnem-se em um só objeto, com desempenho razoável, uma série de funcionalidades, inclusive essa.

Além da questão do controle, vê-se neste texto outra ruptura ou ponto de viragem que se desdobra do fato da tônica dos protocolos metodológicos comumente ser posta na responsabilidade do pesquisador em zelar pela proteção do participante da pesquisa. A preocupação basilar dos comitês e protocolos éticos e dos manuais de metodologia com o risco e o perigo dizem respeito não ao pesquisador, mas aos participantes do estudo (NILAN, $2002)^{3}$, omitindo e deixando de cobrir situações e momentos da investigação em que são os participantes e não os pesquisadores que estão em condições de avaliar os riscos e recomendar estratégias de segurança para viabilizar o estudo e a sobrevivência ao mesmo (BOURGOIS, 1990).

Tendo eticamente fracassado ao conduzir meu engajamento em um sítio específico, em desacordo com o cuidado a mim dispensado por meu principal interlocutor de pesquisa, não busco neste texto super dramatizar o evento, oferecer um relato autocentrado ou etnograficamente estéril (PROBYN apud NI-LAN, 2002), nem tampouco esgotar o tema sobre como minimizar os riscos a que se submetem antropólogos em trabalho de campo. Há

\footnotetext{
${ }^{3}$ Como nos lembra Bourgois (1990), isso tem relação com pressupostos hegemônicos de relações de poder, ancoradouros do legado colonial da nossa disciplina, em que a capacidade de proteger contra danos seria de domínio exclusivo do antropólogo.
} 
um senso comum na antropologia que compreende os nossos achados como indissociáveis das circunstâncias nas quais emergem. Neste sentido, uma primeira versão deste texto compõe o segundo capítulo da minha dissertação de mestrado (VILLANI, 2015), que partiu do estudo de inconformidades de gênero (ou, para simplificar, androginia) e terminou por acompanhar a trajetória de um jovem negro morador de uma favela na cidade de Salvador.

\section{"Descendo a favela"}

Cada dispositivo de poder é um código-território complexo (não se aproximem do meu território, sou eu quem manda aqui...). M. de Charlus arruina-se em casa de Mme Verdurin porque se aventurou fora do seu território e o seu código já não funciona (DELEUZE; PARNET, 2004, p.156).

Eram oito da noite de um sábado quando recebi uma mensagem em áudio de Rafa no whatsapp: "Amigo, vai ter uma festa massa aqui no bairro, velho, você tá onde? Queria te trazer pra cá, você ia adorar”. Ele parecia falar de um lugar barulhento - possivelmente estava já na festa. Como na maior parte das vezes nos encontramos na orla e não na favela, ainda que com pessoas de sua comunidade, eu aguardava há muito um convite seu para subir o morro. Rafa me disse que a entrada na festa era gratuita, que se tratava de um forró que acontecia todo ano, o descrevendo como "bem diversificado, pra você que gosta de conhecer novos lugares. É aqui no bairro da Santa Cruz. Comunidade normal, né, amigo; tem muita gente de bairro, muita gente de fora também, é seguro".

Decidido a juntar-me a ele na tal festa, tomei um ônibus para o fim de linha do Nordeste de Amaralina, complexo de favelas que inclui a Santa Cruz. O ponto de encontro combinado não ficava tão próximo ao local, mas era onde eu sabia chegar. Já no fim de linha do Nordeste, depois de alguns minutos, recebo uma mensagem de Rafa dizendo-me ter tomado a liberdade de "pegar um carro" para ir me buscar, esperando não haver problema nisso (deixando tácito que eu custearia o transporte). Em companhia de um rapaz além do motorista, Rafa foi até mim não de taxi, como imaginei, mas com algum senhor que provavelmente prestava esse tipo de serviço informal em seu próprio automóvel. Na época ainda não existia uber ou similares.

Já no início do trajeto, Rafa, que estava sentado no banco da frente, vira-se para mim vibrando eufórico: “Amigo, tu vai conhecer minha realidade!”. Ambos tínhamos ciência que só até certo ponto compartilhávamos um mesmo mundo, e por isso eu era ali um estrangeiro na "sua realidade" de cores e olores diferentes da minha. Rafa parecia muito contente em poder me apresentar o lugar em que vivia, que estava longe de se caracterizar como um local neutro, mas cheio de significados, teias, relações, e só nesta condição poderia ser referida, por seu próprio direito, enquanto realidade de/para alguém. 
À medida que o carro avançava tornava-se mais nítida impressão de estar cada vez mais in, em um lugar muito mais estreito do que eu estava habituado, o que, somado ao fato de ser noite, fazia-me sentir destituído da liberdade de poder dali sair quando bem entendesse. Perceber-me ligeiramente menos dono de mim mesmo não provocava exatamente um incômodo, pois estava com boas expectativas e acompanhado de Rafa, àquela altura amigo em quem confiava. ${ }^{4}$ Rafa interrompeu meus pensamentos com o efusivo entusiasmo que lhe era característico: “Amigo, tu tá descendo a favela, amigo!!!”.

Ao chegarmos ao local da festa, recebo uma primeira advertência dele: "Olha, aqui você pode andar com seu celular até na cabeça, que ninguém vai te tomar, você só não pode tirar foto”. Ele explicou-me que por ser uma área dominada pelo tráfico de drogas havia na festa muitos homens procurados pela polícia. Soube dias depois por um taxista que o Forró da Sucupira, nome do evento, acontece anualmente há cerca de duas décadas. Segundo o taxista, a festa é financiada pelo tráfico, inclusive os banheiros químicos instalados no local: "Não há apoio do poder público", frisou, deixando transparecer certa admiração pelos homens do tráfico, enquanto o poder público parece ignorar aquela região da cidade.

Embora batizado de forró, no evento também escutava-se funk, pagode baiano e arrocha. Não havia um palco montado ou um centro difusor de música; distribuído entre as vielas, o som mecânico entoava de diversos pontos da festa. Barracas de bebida e comida, ambulantes com isopor vendendo cervejas, gambiarras iluminando o espaço e bandeirolas verdes e amarelas, motivos de Copa do Mundo (o ano era 2014). Muita gente e pouco ou nenhum espaço para dançar, poucas pessoas efetivamente dançando.

Aparentemente, e logo esse dado se mostrará relevante, eu era o único "de fora" em termos de cor, vestimenta, e possivelmente em gestualidade; em termos de corporeidade de modo geral. Muito gentis e receptivas, as amigas de Rafa agiam inicialmente como se eu estivesse intranquilo, insistindo que ali era "de boa", que eu poderia me sentir seguro etc. A despeito de ainda estar me ambientando, acredito que eu não aparentava desconforto, porém, em virtude de eu não ser "da área", entendi a preocupação cuidadosa das moças em me oferecerem o maior senso de segurança possível.

Como passamos um tempo parados em um ponto específico da festa e eu tinha interesse de conhecer mais o lugar, disse que daria uma volta sozinho; me sentia, senão seguro para isso, despreocupado. Havia muita gente e as ruazinhas eram demasiado apertadas, qualidade potencializada com as barracas alocadas tanto de um lado como de

\footnotetext{
${ }^{4}$ Uma reflexão interessante sobre as implicações de ambientes mais inacessíveis, por assim dizer, para a segurança do pesquisador, ou lugares dos quais este não pode sair sozinho, está disponível em Sampson e Thomas (2003), mulheres que realizaram trabalho de campo em alto mar (ou seja, em um contexto de afastamento extremo, de dias a bordo), em um navio cuja tripulação era composta apenas por homens.
} 
outro. O espaço para transitar era comprimido, o que fazia com que grupos de amigos se dispusessem em fileira quando moviam-se de um canto a outro da festa.

Meu primeiro estranhamento ou sobressalto naquele espaço foi quando um jovem, que era o primeiro de uma dessas fileiras, passou com um revólver em punho - dono de um metálico quase cintilante, inconfundível. Calmo, mas intrépido, ele dizia "bora, bora", ao passo em que movimentava a mão desocupada como quem solicitava que dessem licença para que ele e seus pares passassem. A cena não me assustou muito, isso por conhecer narrativas em linguagens tanto etnográficas quanto cinematográficas ou televisivas, de bailes funks em favelas cariocas. Porém não deixou de chamar minha atenção no sentido de me situar em relação ao ambiente, que àquela altura constituía- se decididamente enquanto um espaço outro para mim.

Ainda caminhando sozinho, apenas observando, encontrei Gabriela, travesti amiga de Rafa com quem já havíamos saído. Nos cumprimentamos com muito alvoroço e fizemos uma linda foto no meu celular, na qual, fazendo troça, ela empinava a bunda pra mim e abria um enorme sorriso. Pouco depois, acompanhado de Gabriela, voltei ao encontro de Rafa, que ao ver-nos juntos brincou: "Pronto, já se achou!", convencido que estava naquele momento de que, tendo até mesmo conhecidos por ali, já me sentia à vontade na festa.

Em dado momento, depois de Rafa e os amigos buscarem um lugar deserto para grelhar ${ }^{5}$, eles sentiram vontade de urinar. Descemos algumas escadas ou ladeira - já nem me lembro ao certo - até onde havia dois banheiros químicos. Rafa urrava enquanto esperava na fila, daí um rapaz, conhecido seu, que tinha acabado de usar o banheiro, o inquiriu: "Tá passando mal, bicha?". Rafa então me disse que a pessoa naquele espaço tem que "ter visão ${ }^{6}$ pra não levar uma 'maquiagem definitiva". Não entendi o que quis dizer com "maquiagem definitiva" e, como Rafa tinha acabado de adentrar o banheiro, seu amigo me explicou: "Uns cascudos na sua cabeça toda lindinha”.

Eles me disseram então que era proibido urinar em qualquer lugar durante a festa, que isso só podia ser feito nos banheiros químicos, bem como era vetado brigar ou roubar. Alguns dias depois conversei com um jovem que vive naquele bairro e ele disse que os traficantes locais estão cada vez mais inflexíveis quanto às infrações aos códigos de conduta impostos por eles; com relação àqueles que roubam na área, "não tão nem mais batendo, já tão matando". Ou seja, os bandidos garantem "a inviolabilidade de sua área" (ZALUAR, 1985, p. 143).

O tráfico de drogas instaura na comunidade, como se pode ver, um sistema moral particular, que funciona como dispositivo de controle social, o qual por sua vez exige todo

\footnotetext{
${ }^{5}$ Gíria que designa inalar cocaína.

${ }^{6}$ A expressão "pega visão" ou "toma visão" pode ser traduzida como uma advertência do tipo "se liga!". Prescreve atenção e cautela.
} 
um autocontrole por parte dos sujeitos, cientes das sanções que podem desencadear a prática de uma conduta proibida. O repertório de interditos varia desde o que pode ser considerado trivial por alguns, como urinar em qualquer lugar, principalmente em uma situação de festa (prática muito comum nas festas populares da Bahia), a uma ação judicialmente criminalizada, como roubar alguém. De caráter ordenador, a violência aparece na qualidade de um padrão de referência familiar e cotidiano, assim como, em sua forma sumária, como resolutória de conflitos (ROCHA, 1999; FELTRAN, 2007). As pessoas que estão submetidas ao juízo da facção local têm "de aprender a conviver com as formas despóticas de poder" (ZALUAR, 2012, p. 332), não estando alheias à ética própria às facções (BIONDI, 2018, p. $308)$.

\section{Infortúnios em campo}

Depois de utilizarmos o banheiro voltamos para onde estávamos inicialmente. Rafa e suas amigas queriam circular, enquanto preferi ficar parado fumando um cigarro. Leila, amiga de Rafa, sob o argumento de que as pessoas estavam fumando por toda parte e que não havia problema que eu caminhasse fumando, tentou persuadir-me a seguir com eles, todavia eu realmente não estava com disposição de ficar com a mão estendida ao alto (a fim de não atingir alguém com a chama do cigarro). Rafa insistiu em ficar comigo, contudo, embora primeiramente tenha resistido à ideia de deixar-me só, o convenci a ir com as meninas, pois percebi que ele queria circular um pouco pela festa. Eis que Rafa me disse para eu ficar em companhia do seu amigo, o mesmo que foi no carro com ele me buscar no fim de linha do bairro, e que conosco permanecia.

Acontece que pouco depois de Rafa sair para dar uma volta com suas amigas o rapaz resolveu ir embora e lá fiquei sozinho. Ora, ficar sozinho nunca foi um problema para mim, pois tenho muito gosto em engajar-me na atividade de observação. Lembro que cheguei a fazer foto de um "boyzinho" que estava dançando por perto, mas discretamente: fingia fazer alguma ligação telefônica quando na verdade pressionava um botão na lateral do celular que disparava o registro fotográfico (sem flash), ou simplesmente simulava a escrita de uma mensagem quando na verdade o fotografava. $\mathrm{Na}$ fragilização da fronteira entre trabalho e lazer não raro resultante da oscilação entre observar e participar, admirar os rapazes bonitos, ou "os novinhos periféricos", como Rafa costumava a eles se referir, compunha prática fundamental da empatia construída entre mim e ele. Depois de passar um bom tempo sozinho, fumando e bebendo, decidi-me por sair à procura de Rafa na direção em que ele seguiu com suas amigas. Não o liguei, pois, como me havia dito Leila, todos os celulares do grupo já estavam descarregados.

Ao chegar onde seria o fim da festa e não encontrar nem Rafa nem suas amigas, parei em um lugar em que havia algumas garotas dançando funk. Achei a cena bonita, fiz umas 
duas fotos, ainda de modo discreto - também sem acionar o flash, evidentemente. Fui então surpreendido com a chegada de um homem muito bruto, que devia beirar os trinta, barba por fazer, forte, tatuado e com corrente prateada no pescoço, do estilo "batidão": "Tá fazendo foto do que aqui, mermão? Vá, me dê esse celular aí", interpelou-me. Estremeci.

Apenas nesse momento lembrei da primeira coisa que Rafa me dissera quando aportamos na festa. Na minha memória o escutei - ele, familiarizado que estava com esse meu hábito - novamente dizer: "aqui você só não pode fazer foto". Só uma visão que, enquanto prática, e refiro-me aqui a uma prática situada, é adestrada no "modo de suspeita" (RABELO, 2015, p. 246), quer dizer, que tem a desconfiança como disposição e premissa, poderia ser tão habilidosa como a do cara que avançou até mim, tornando os objetos a que se deve interrogar inescapáveis. O inspirador trabalho da antropóloga Miriam Rabelo (2015) sobre o aprendizado algo difuso da visão em um domínio de prática particular - qual seja, no candomblé - nos mostra como ela pode não começar exatamente nos olhos, mas na experiência de suspeita. É como os adeptos desta religião aos poucos passam a apreender o mundo; ao abandonar o que seria uma "visão ingênua", adquire-se uma visão mais expandida, que lhes permitem traçar conexões com o que não está imediatamente visível aos olhos. Logo se verá as associações que fizeram sobre mim.

Aos poucos vi se aproximar um, dois, três, quatro homens junto ao primei- ro, e lá estava eu, do alto do meu pouco mais de 1,60 m de altura, que, tomado pelo pavor, me percebia ainda mais diminuto do que já sou, agora diante desses homens muito homens, enormes com seus revólveres e correntes. Estava um pouco afastado do restante do público da festa, que, fosse quem fosse, nada poderia com eles. Quando viram seu comparsa me arguindo com um celular na mão, entenderam de pronto que eu estava fazendo registros fotográficos da festa, dispensando qualquer contextualização por parte do primeiro.

De pronto levei dois fortes socos nas costas de um brutamontes - não bastante fortes, é verdade, para deixar a região dolorida por mais tempo. Foi uma dor aguda mas instantânea. Como que instintivamente, afastei-me dando dois passos adiante, me aproximando mais, porém, de um outro homem que tinha se posicionado na minha frente: eu estava rodeado, totalmente ilhado. O que me agrediu disse com certo cinismo: "Ei, volte, não vá se saindo não”. Então voltei atrás com tímidos passos, e ele deu a voz: “Aqui não pode tirar foto, não!". E eu, fazendo o desavisado, disse com voz mansa de coitadíssimo: "Pois é, desculpa, eu não sabia disso..."

O primeiro a me abordar, já a conferir as fotos que eu tinha feito na fes- ta, disse, certamente ao ver as fotografias das meninas dançando: “Ah... Você é donzelo, né?”. E os outros riram, enquanto eu, com o coração saindo pela boca, nada respondi. Ao passar a outra foto e deparar-se com o "boyzinho" que cliquei, ele falou: "Hum, na verdade você é viado, né?”. Então o rapaz que estava bem diante de mim, de cabelo encaracolado e meio tingido de 
louro, quase na altura dos ombros, com um dente podre na boca e batidão de prata no pescoço, disse: "Vem cá, se você é viado então eu posso enfiar o cano no seu cu, né?". Ao que respondi temeroso: “Não, velho...”. E ele continuou: "Mas o cano que tou falando é o cano do revólver."

O interrogatório continuou: "Você tem cara de que é do Bocão ${ }^{7}$, né?". E eu respondi, pensando que realmente, com meus oclinhos de aro grosso, devia estar a própria personificação do jornalista: “Não pô, eu odeio o Bocão!”. Depois ele perguntou: "Você tem cara que queria mandar foto pra polícia, que é amigo de polícia”. Me sentindo quase ofendido em ser associado com essa instituição, falei: “Não, velho, eu odeio polícia!”. E ele, possivelmente incrédulo: “Ó, não traga suas putas ${ }^{8}$ pra cá, não, que a gente vai queimar todas elas.”. Enquanto que o amigo que estava na sua frente falou: “É, e a gente vai te queimar também, e te matar". Foi quando aplicou-me dois socos no abdômen, provocando qualquer dor que não me era facultado sentir, e que senti tanto ou tão pouco como os primeiros golpes. De repente ele sacou do bolso um spray cujo rótulo não consegui identificar e um pedaço de estopa, e me ocorreu que eles pretendiam me desacordar ou mesmo me queimar.

Como bem pontua Pamela Nilan (2002) a partir de sua experiência de campo durante um momento político bastante conflituoso na Indonésia, "o tipo de medo que você experimenta em tais ocasiões é difícil de descrever” (p. 373, tradução minha). Como ela, que deitada sobre o chão da casa protegia-se com lenços umedecidos sobre a boca e o nariz da fumaça tóxica advinda da rua sob ataque, pensei rapidamente nos entes queridos que poderia não voltar a encontrar.

\section{A fotografia e o controle sobre o visível}

Nestór Perlongher, refletindo sobre a constituição da alteridade na antropologia (enquanto uma "ciência do outro"), brinda-nos com o trecho seguinte, cuja reprodução na íntegra é útil para pensarmos de que lado inevitavelmente eu estava alocado naquela situação etnográfica:

Imaginemos uma cena de um filme que poderia chamar-se algo assim como 'Tempestade no Paraíso': ilha polinésia, vendaval, coqueiros agitando-se, nativos dançando seminus estilo 'Tabu' e uma comitiva ocidental desembarcando no porto: o administrador colonial, de roupa de linho branco e chapéu Panamá, o soldado de uniforme, às vezes o padre de batina, e, à parte, meio marginal, 'quase brechtiano', um personagem estranho, de óculos: o antropólogo. Nessa situ- ação estritamente

\footnotetext{
${ }^{7}$ Referência ao “Se Liga, Bocão!”, programa televisivo policial da Bahia de cunho assaz sensacionalista.

${ }^{8}$ Em conversa com Rafa e suas amigas a posteriori, descobri que "putas" devem ser entendidas como policiais.
} 
imaginária fica claro de que lado está o antropólogo - do lado da autoridade - e está claro quem são os outros: os nativos polinésios (PERLONGHER, 1993, p.2) ${ }^{9}$

A verdade é que pouco me deixavam explicar qualquer coisa ou estender- me nos argumentos que em vão ensaiava. E, talvez, nervoso que eu estava diante daquela situação tão inédita quanto inusitada, nem mesmo estivesse em condições de elaborar um discurso que pudesse resultar na minha absolvição ou escapatória. Eis que, finalmente - acredito que para a minha grande sorte

- o primeiro a me abordar vê minha foto com Gabriela:

“Ó aquela bicha...” "Gabriela...”, disse o outro.

"Sim pô, ela que me convidou pra vir pra cá. Nós somos amigos", aproveitei a "deixa".

O interrogatório deve ter continuado um pouco mais, e eu, no ímpeto de negociar e antecipar minha liberdade, determinei: "Podem ficar com o celular" -todavia fui interrompido pelo homem de dente podre que estava na minha frente: "Mano, ninguém aqui quer seu celular não, aqui todo mundo tem tudo" - e levantou a camiseta, estando do lado direito da sua cintura um revólver e do outro um smartphone, que ele tirou para me apresentar. Não sou um exímio conhecedor de novidades tecnológicas, mas arriscaria dizer que o dispositivo devia se tratar de um dos últimos lançamentos. Se eu achava que me veria livre acionando esse modo corriqueiro de barganhar com os meliantes, entregando de uma vez o celular, estava redondamente enganado. Então mandaram eu tirar o cartão de memória do aparelho (deixando para trás os registros), porém, para o meu desespero, meu celular nem cartão de memória tinha. Só depois do ocorrido, reflexivamente entendi que o fato de eu ter feito a tal foto das garotas de modo discreto colocou-me ainda mais em suspeição.

Jeffrey Sluka (2007), em trabalho cuja leitura, acredito, caso feita antes do início da pesquisa, possivelmente evitaria tamanha inconsequência de meu comportamento, alerta para o fato de que geralmente o antropólogo, este sujeito algo extraordinário em determinado campo, será definido pelos nativos com referência a categorias preexistentes. Jornalista, polícia, espião, missionário são exemplos dessas categorias, oriundas da experiência com outros estranhos que apareceram na comunidade, tantas vezes aplicada (erroneamente) aos antropólogos. Ora, como é provável que as pessoas em questão nos definam, incauto, não me antecipei à recomendação de Sluka, "evitando agir de maneiras que possam reforçar essas suspeitas” (p. 264, tradução minha). Ser definido como um espião,

\footnotetext{
${ }^{9}$ Agradeço à Professora Larissa Pelúcio por chamar minha atenção para esse texto.
} 
argumenta o autor, "é inerentemente perigoso" (p. 264, tradução minha). Em referência ao trabalho de Myron Glazer, ele completa: se você não quer ser definido enquanto tal, "então não seja ou não aja como um" (p. 264, tradução minha). ${ }^{10}$

Passado um tempo, eles afinal disseram, entregando-me de volta o celular, acompanhado de um empurrão: "Vai, vaza daqui!". Não deixa de ser irônico que, se num primeiro momento a fotografia, ou melhor, o ato de fotografar outrem, me colocou em apuros, ulteriormente foi também uma fotografia que contou para que a suspeita de que seria eu um infiltrado se diluísse. Pouco depois de sair daquela rodinha estava aos prantos, e, ao me meter na multidão, onde me senti solitariamente acolhido no meu tormento, dois colegas com quem já havia me divertido casualmente - um deles gay e a outra bissexual encontraram-me no auge do meu desafogo e perguntaram o que tinha acontecido. Mal conseguia explicar-me, quando apareceu Rafa: "Meu Deus, aquilo que eu mais temia aconteceu!". A festa evidentemente acabara ali, ao menos para nós. Rafa me levou para a casa de uma amiga onde ele estava hospedado, nos acompanhando Leila, os dois colegas que me encontraram e mais uma amiga de Rafa.

Embora essa situação tenha sido bem mais dramática, lembrei-me de Wacquant; na sua pesquisa em clubes de boxe no subúrbio de Chicago, igualmente munido de uma tecnologia produtora de registro - mas, no seu caso, apenas de áudio (um gravador) - fora recomendado por seus colaboradores de pesquisa a ser discreto com o instrumento, porque, diz ele:

os marginais que agem na área poderiam achar que eu sou um policial undercover ou um agente do FBI. Percebi que o técnico do Woodlawn não estava brincando alguns dias depois dessa reunião, quando Jack Cowen voltou ao assunto, numa conversa no gym: "Louie deve estar corren- do altos riscos com esse gravador, com todos esses gatu-nos que andam por aí. Se ele continuar passeando assim com esse gravador, uma manhã dessas pode ser que a gen-te encontre um cadáver do outro lado da estrada de ferro" (WACQUANT, 2002, p. 212).

Alba Zaluar (1985), no seu já clássico estudo A máquina e a revolta, produzido em um tempo em que dispositivos fotográficos não eram tão difundidos como hoje, não apenas

\footnotetext{
${ }^{10}$ Quanto a este aspecto, uma das estratégias das quais Marques (2016) lançou mão na sua etnografia com "ladrões", que o reconheciam como alguém “dos direitos humanos", e portanto como um aliado e não como um oponente, foi indagar como se deu e não quem executou determinadas ações - diferindo sua abordagem de uma investigação policial. Também para seus interlo-cutores era interessante acolher a sugestão do próprio pesquisador em abstrair ou mesmo recusar-se a mencionar nomes, locais e datas, possíveis indiciamentos para estes.
} 
aprendeu bastante com a mediação da câmera fotográfica no seu campo, a Cidade de Deus uma das maiores favelas cariocas -, como pôde encontrar um modo de oferecer algo em troca para os colaboradores do seu trabalho. Porém, sempre que se "aventurava por áreas do conjunto onde não era bem conhecida" (p. 22), seu ato de fazer fotos era visto como suspeito, podendo inclusive sofrer alguma espécie de ameaça de moradores que receavam que os dados produzidos fossem entregues às autoridades policiais.

Jenifer Rogers-Brown (2015), por sua vez, percebeu que acionar a câmera fotográfica em uma marcha na Revolta de Oaxapas, violento protesto popular ocorrido no México, podia poupar-lhe de ser detida ou ferida, pois, em vez de manifestante, a fotografia naquele contexto a posicionava no lugar de turista ou repórter. $\mathrm{Na}$ interessante reflexão que tece sobre os dilemas éticos que circundam a inserção do dispositivo fotográfico na incursão etnográfica, relata ter sido interpelada por um jovem ativista que, enquanto ela fazia fotos, quis saber quem era, ao que ela apresentou sua carteira de estudante de pós-graduação e argumentou apoiar a causa. ${ }^{11}$ Rogers-Brown também testemunhou jovens pichadores intimidarem um homem branco que os fotografava até ele apagar as fotos que tirou. $\mathrm{Na}$ ocasião ela fez fotos das mesmas cenas, mas ou não foi percebida ou não era vista como ameaça (ameaça evocada, por exemplo, pela figura de uma jornalista que poderia publicar essas fotos). De modo geral, a antropóloga pedia permissão para tirar retratos, ou ocupavase antes de observar a reação dos atores envolvidos quando outras pessoas lhes fotografavam. Porém, como muitas fotografias registravam atividades consideradas ilegais, ela nunca fazia fotos dos rostos das pessoas.

Como o que ocorreu comigo, outros casos que merecem uma reflexão ética por parte de nós, antropólogos, são relatados por Larissa Fontes (2015), e dizem também respeito à feitura de fotografia, mas em contexto religioso, nomeadamente no candomblé. Um deles é um depoimento extraído da obra de Vagner Silva, concedido pelo antropólogo Roberto Motta, que diz: "numa obrigação de Balé que Manuel [pai-de-santo] não me deixou olhar, eu abri a porta e tirei um retrato. E quatro meses depois eu tive um diagnóstico de um problema na vista tão sério que eu fiquei achando que era castigo. Até hoje eu acho que foi castigo" (SILVA, 2006 apud FONTES, 2015).

Mais adiante ela nos traz a fala da antropóloga Janecléia Rogério, que, como Roberto Motta, atribui o que sucedeu à sua "teimosia" à agência de uma entidade: "as fotos saíram pretas. Eu estava com uma câmera digital e outra analógica. Não tem explicação. A dona da

\footnotetext{
${ }^{11}$ Peritore (1990) afirma não saber o que lhes aconteceriam, a ele e a seu colega de pesquisa, caso não estivessem em posse do seu cartão da universidade quando, ao fazerem pesquisa em um assentamento pró Reforma Agrária em Goiânia no final dos anos 80 - cenário em que se era constantemente ameaçado pela polícia e por capangas de latifundiários -, foram surpreendidos por um dos líderes da ocupação: "Como podemos saber que vocês não são da polícia ou da CIA? Vocês têm como provar que não são nossos inimigos?” (p. 369, tradução minha).
} 
casa [a ialorixá] disse que a entidade tinha dito que não podia fotografar. Eu fotografei de teimosia. Você sabe, às vezes a gente faz isso...” (p. 72). Segundo Fontes e sua leitura de autores tão diversos quanto Susan Sontag, Jérôme Souty e Lisa Castillo, as ressalvas do candomblé em relação à fotografia teria, em suma, relação com o poder que o fotógrafo estabelece com o objeto da fotografia (seja em termos propriamente mágicos - quer dizer, de feitiço - seja em relação a um contexto repressivo mais amplo), em que o sujeito fotografado não detém o controle da imagem.

Castillo (2013) argumenta que "não é apenas pelo fato de existir um registro. Mais importante ainda é a questão de onde irá circular e quem terá acesso” (p. 59). Assim, as restrições à fotografia naquele contexto visam garantir o controle da comunidade religiosa no que tange à produção e circulação de imagens. Mais uma vez aqui, guardadas as devidas proporções, podemos encontrar paralelo com a proibição da fotografia no local em que estive, sobretudo em tempos de conectividade; hoje, no limite, nem a própria pessoa que fotografa controla facilmente a circulação e concomitante repercussão da imagem produzida. Devo de resto dizer que diversos trabalhos (ver, por exemplo, OPIPARI; TIMBERT, 2014, p. 388-9) sinalizam certo acautelamento para introdução de câmeras em localidades controladas por facções.

Finalmente, Philippe Bourgois (1990) salienta que, diferente de notas escritas, que podem ser codificadas pelo etnógrafo a fim de proteger não somente seus interlocutores como por vezes a si mesmo, uma gravação de voz ou uma fotografia são linguagens que dificilmente podem ser manipuláveis ou obscurecidas neste sentido. Por isso Bourgois considera uma questão es- sencial não fazer fotografias no trabalho de campo de modo indiscriminado, bem como, no afã de tudo registrar, ponderar o que deve ou não ser tomado nota, novamente mirando os riscos implicados; em alguns casos, mais vale apostar tãosomente nos registros da memória.

\section{A fotografia seguida da revelação}

O fato é que depois de me terem levado para fora da festa fomos para a casa em que vive uma amiga de Rafa com o tio. Ele costuma pernoitar nessa casa quando sai para curtir, a fim de evitar chegar em sua própria casa com aparência de "drogado" e desapontar sua mãe, "evangélica". Primeiramente, ofereceram- me água, que gelava numa garrafa plástica verde, originalmente de refrigerante. O quarto estava meio caótico, como o de um folião em pleno carnaval, que mal tem tempo ou disposição de pôr ordem no espaço: dorme, acorda, parte pra rua, volta pra casa, dorme outra vez. Cama desfeita, paredes um pouco sujas, papelão na janela servindo de cortina, um caco de espelho jogado em algum canto do quarto, um pequeno e pouco acabado apanhador de sonhos atrás da porta, que no momento servia para 
pendurar uma toalha de banho a secar, um ventilador cujas hélices já não eram cobertas por uma capa protetora: foi onde me senti mais seguro e confortável naquela noite.

Sentia-me entre amigos, pessoas que se importavam comigo, e o fato do quarto ter poucos metros quadrados só expandia a sensação de ninho, de proteção do "mundo lá fora". Sentei-me na cama com eles e, vez ou outra, ainda bastante fragilizado, deitava, enquanto escutava com interesse os casos de Rafa e de seus amigos.

Leila disse que na área dela badala, mas que em área dos outros prefere nem se mexer, "pra não ficar com tapa tomado, ainda mais que mulher é tudo recalcada". "Até porque", acrescentou, "eu gosto de vestir minhas roupas de piriguete. Em área dos outros eu me planto, porque camarão que dorme a onda leva". E Rafa toma a palavra: "Eu também já fui vítima da favela”. Em seguida abaixa a cabeça e mostra-me uma cicatriz um pouco acima da nuca.

Partindo do pressuposto de que a favela é um lugar e que este sempre o é para alguém - por exemplo, para quem o habita - não é possível falarmos de um lugar desprovido de sentido, ou, pelo menos, que não seja primordialmente relacional. Portanto, favela é um lugar, mas um lugar tal qual parece a Rafa, a ela fazendo menção quase como um sujeito. A favela só pode assumir tal acepção na sua narrativa, isto é, de uma entidade dotada de agência, na medida em que é capaz de sintetizar a configuração, um feixe de um sem-número de relações sociais marcadamente assimétricas e hierárquicas, sendo passível de, enquanto algoz, causar dano a alguém.

Rafa contou que na época em que era travesti chegou a trabalhar para o tráfico. Durante um carnaval, perdeu a droga que estava com ele (e que deveria ser vendida). "Ainda bem que você não levou uma coronhada", disse. Coronhada foi o que the rendeu a cicatriz na cabeça. A mim, que nunca havia escutado o vocábulo - o que pode indicar pouca familiaridade com circuitos mais violentos - explicaram que designa o ato de perfurar, com o auxílio do cano do revólver, a cabeça do sujeito, sem, contudo, atirar. Ou melhor, empunhar o cano do revólver contra a cabeça de alguém. Rafa me disse que na ocasião a companheira do traficante queria que ele fosse morto; isso não aconteceu porque, ao implorar pelo celular para o "chefão" que lhe deixasse vivo, ele assim ordenou aos seus subalternos.

Depois dessa situação, Rafa precisou cortar o cabelo no lugar em que fora machucado, a fim de que a ferida aberta na sua cabeça pudesse cicatrizar. Naquele período se afastou da cidade e se instalou na casa de amigos de seus familiares em um município localizado a cerca de $50 \mathrm{~km}$ de Salvador. Cortou todo o cabelo também para se socializar com mais facilidade na sua nova morada. Esse momento pode ser uma espécie de marco na sua vida, pois se conjuga com o abandono da identidade travesti. É possível perceber que já não nasce cabelo 
na parte da cabeça em que está localizada a cicatriz, uma das razões pelas quais, mais tarde, e a fim de escondê-la, Rafa voltou a cultivar suas madeixas.

Rafa e seus amigos chegaram à conclusão de que os homens do tráfico ficaram com pena de mim, mas que "se fosse outro...". Talvez a suposta indulgência deles para comigo tenha relação com o fato de que eu não era, como sinaliza-ram meus amigos do Nordeste de Amaralina, "qualquer homem", mas um homem com trejeitos femininos, ou talvez, sendo "reduzido" à categoria de viado, nem mesmo chegasse a sê-lo. Claro está: nenhum corpo é neutro; tampouco o corpo do pesquisador o seria. Assim, acolho a sugestão de Jenifer Rogers-Brown (2015), que, preocupada em como o perigo na pesquisa "pode impactar desproporcionalmente os pesquisadores mais suscetíveis a riscos específicos" (p. 112, tradução minha) - como as mulheres ${ }^{12}-$, recomenda analisarmos a identidade do pesquisador na mediação do perigo no trabalho de campo. Se alhures ser um homem afeminado poderia vir a tornar-me mais vulnerável, não ser um homem masculino e não dispor de grande porte físico (a bem dizer, ser um sujeito mirrado) contou, naquele ambiente, a meu favor. Essas marcas corporais possivelmente suscitaram a leitura de mim como alguém não ameaçador, podendo mesmo responder pela minha sobrevivência e consequente viabilidade de relatar esse conflituoso evento.

Ficamos mais um pouco no quarto enquanto aguardávamos o ponteiro do relógio marcar cinco da manhã, tempo o bastante para que o público da festa regressasse às suas casas, as ruas estivessem menos escuras, e também por conta dos ônibus, que começavam a circular naquele horário.

Antes de sairmos da casa em que estávamos, eu e Rafa olhamo-nos, ambos ainda abatidos, e eu lhe disse:

“Ô, meu bem, continuaremos a nos ver, viu? Mas lá embaixo”, brinquei.

"Como eu gosto; não ando por aqui. Agora que você viu como minha realidade é terrível...”, respondeu.

Intuo que, vide o "agora que você viu como minha realidade é terrível", experimentei, ainda que de modo bastante pontual, estar submetido às regras impostas pela facção, bem como possíveis implicações (talvez não a menos branda, mas nem por isso pouco violenta) de descumprir os códigos de conduta vigentes. O dissabor por que passei, e que teve ressonância em Rafa, parece ter suscitado algum nível de aproximação entre mim e os

\footnotetext{
${ }^{12}$ A autora considera as identidades interseccionadas (de gênero, raça, nacionalidade, religião, etc.) tanto em termos de oferecer segurança para o pesquisador - engajado, via observação participante, em determinado contexto - quanto em termos de acesso e inserção no campo, conquistando a confiança dos interlocutores da pesquisa. A esse respeito, conferir também Sharp e Kremer (2006).
} 
moradores do lugar, que também já foram vítimas ou que ao menos entendem com muita propriedade o que é viver sob o jugo do crime organizado.

Neste sentido, são sintomáticas todas as narrativas - as que aqui trouxe e aquelas que suprimi ${ }^{13}$ para não exaurir o leitor - desencadeadas por minha desventura, as quais de outro modo (caso o etnógrafo tivesse respeitado a orientação de seu colaborador) não teriam emergido. Todavia, ao reconhecer que o meu deslize acabou por ser produtivo e revelar certas nuances - trazer à tona eventos pessoais da vida de Rafa e da sua rede de amigos e vizinhos -, não quero poupar a gravidade da minha irresponsabilidade, ainda que não pudesse deixar de sublinhar o fato de se tratar "de uma história revelada através da experiência" (MINTZ, 1984, p. 54, grifos do autor).

Mesmo que eu tivesse, enfim, sido visto pelos traficantes como "alguém de fora", naquele momento eu ocupava o lugar de assujeitamento a determinada lei. Essa "comunicação específica" que se abriu "com os nativos" (FAVRET-SAADA, 2005, p. 159) talvez seja indício de que, ainda que à minha revelia - a bem dizer, de modo não voluntário e não intencional - eu tenha sido afetado. Quero com isso afirmar o óbvio: não escolhi ser afetado nesses termos. Rafa, ao me encontrar e me ver tomado pelo choro, reconhece que eu havia transposto uma barreira entre mim e eles; ali já não havia distância, eu tinha experimentado a face cruel da vida na favela: "Aquilo que eu mais temia aconteceu". O uso da câmera, que me posicionava em um ponto algo cômodo de observador, terminou por suscitar de modo violento a minha efetiva participação: no fundo, ao fazer recurso à câmera eu já estava agindo.

\section{Outros desdobramentos}

Estive com Rafa na favela, em momento anterior a essa desventura mas não a seu convite, apenas outra vez. Em ocasião diversa declinei quando ele e sua amiga me chamaram para um "paredão" noutra favela. Na altura ainda não me sentia seguro, e não somente em virtude desse assombroso episódio, mas também por conta de outra situação de violência sofrida, também durante trabalho de campo. Nesta última tratou-se de um ataque mais gratuito, em que eu nada tinha feito além de ser um "estrangeiro", o único "branco" e de classe média no local, para despertar a ira do perpetrador (VILLANI, 2015, p. 83-4).

Como é de se supor, o meu texto não ficou incólume a isso. Embora não raro Rafa declarasse não gostar do lugar em que vive, e se esforçar para fazer de si mesmo como que distinto de parte dos seus vizinhos - especificamente das "bichas da favela", como os denominava - eu também sabia que ele era capaz de se divertir na periferia, pois frequentemente, acompanhado de amigas heterossexuais, participava desses "paredões" a que fui convidado. Eu sigo me sentindo desconfortável pelo fato da dissertação, em razão de

${ }^{13}$ Cf. Villani (2015, p. 79-80). 
minha irresponsabilidade, contribuir de algum modo com a reprodução do imaginário reduzido e perverso de que favela é lugar em que "apenas" a violência tem cena.

Preocupado com tais implicações (políticas) de meu trabalho monográfico, tentei em variadas oportunidades propor a Rafa que compartilhasse comigo experiências positivas lá vividas, sobretudo aquelas relacionadas a lazer, festa e entretenimento, porém ele resistia, sendo monossilábico, desconversando ou simplesmente frisando não gostar. Devo dizer que isso não aconteceu apenas com relação a esse tópico, mas com vários outros. Rafa afinal me ensinou que eu só aprenderia com ele o acompanhando, permitindo que o sujeito da pesquisa tornasse sua própria agenda proeminente no trabalho, e não a do pesquisador - isto é, assumindo efetivamente um nível de autoria. Não tardei a entender que o estabelecimento dessa cooperação só funcionaria se motivado pelo interesse do sujeito que autorizou que eu fizesse parte de seu rol de amigos.

Aliás, lançando agora um olhar menos engessado para as dicotomias favela/orla, asfalto/morro, e mirando uma vez mais para minha etnografia, considerar como orla um dos ambientes privilegiados dela, o Mercado do Peixe do Rio Vermelho, local onde eu e Rafa mais nos divertimos, seria no mínimo uma leitura apressada, negligenciando a subversão operada sobre os sentidos de "orla" pelas pessoas que o ocupavam naquelas noites. ${ }^{14}$ Elas passavam a largo dos circuitos de consumo do bairro boêmio, como é conhecido o Rio Vermelho, desde os próprios bares/restaurantes do Mercado do Peixe - a partir dos quais situava-se do lado oposto. E tomavam o espaço com seus corpos negros, jovens e pobres, corpos em movimento, a coreografarem uma música que possivelmente os racializava ainda mais: entoado nas alturas desde os sons automotivos dos carros que ali estacionavam, o pagode baiano. Aquilo parecia embaralhar a identidade do lugar, atraindo a atenção das autoridades policiais que interrompiam a diversão da turma e a dissipava com batidas cada vez mais frequentes. Não é de se estranhar, aliás, que com a execução do projeto de requalificação do bairro do Rio Vermelho não haja mais possibilidade que emaranhamento semelhante seja disposto na estrutura arquitetônica assumida pelo Mercado do Peixe, que deu lugar à Praça Caramuru.

Seja como for, evitar a favela (pensada aqui de modo mais estrito) tornou- se incontornável depois desses eventos, vez que, para além dos decretados interditos, nossas emoções, ocasionalmente experimentadas também por quem está situado naquela configuração de campo (EMERSON; FRITZ; SHAW, 2011) - e que por isso não podem ser simplesmente desprezadas -, mediam a atividade de observação.

\footnotetext{
${ }^{14}$ França (2012, p. 27) estabelece uma discussão com a literatura acerca da instabilidade e heterogeneidade das significações dos lugares, bem como da volubilidade de suas fronteiras. Citando a geógrafa feminista Linda McDowell, defende que marcadores sociais, como gênero, raça/cor, classe, idade, sexualidade, entre outros, produzem significados diferenciados para diferentes lugares. Esses sentidos, portanto, não são fixos.
} 


\section{Considerações finais: "saber entrar e saber sair"}

Mormente quando os nossos pares são uma rigorosa comunidade científica, tendemos a compartilhar e tornar público apenas os nossos acertos, reservando descuidos e equívocos, na melhor das hipóteses, ao diário de campo. A decisão aqui foi de tirar debaixo do tapete a minha falta, rejeitando o prodigioso lugar de iniciante impecável, que por vezes sustentamos às custas de poeirentas (auto)censuras.

Os percalços que este jovem e inexperiente antropólogo que vos fala atraiu para si podem servir de lição de como (não) se comportar em um contexto de trabalho de campo, principalmente se perigoso - quer dizer, em um lugar conhecido por aplicação regular de violência. Assumir a culpa e a gravidade do deslize que cometi é primeiro reconhecer que, para além do perigoso per se, posso tornar o ambiente mais ou menos arriscado a depender do modo como nele me engajo, e depois há que compreendermos como os acontecimentos foram determinantes na produção de um tipo de representação e não de outra.

É dessa forma que entendemos que os "achados" não são absolutos ou invariantes, mas inseparáveis das circunstâncias de sua "descoberta" (EMERSON; FRITZ; SHAW, 2011).

Não é possível precisar quais rumos teriam tomado a etnografia caso eu não tivesse provocado aquilo por que passei, da mesma forma que é vão tentar mensurar o quanto eu poderia ter prejudicado meu anfitrião caso ele estivesse ao meu lado no momento em que acionei o dispositivo fotográfico. Teria ele sido rápido o bastante e tomado o aparelho da minha mão, interditando minha ação? Teríamos sofrido a intervenção dos trabalhadores do tráfico ao verem que eu estava acompanhado por alguém "da área"? A violência emergiria como tema relevante no trabalho, como de fato revelou-se na trajetória e no traçado de projetos pessoais do meu principal interlocutor? Qual reverberação teria sobre a minha pesquisa caso o objetivo fosse estudar a relação entre determinados sujeitos e o espaço em que vivem? ${ }^{15}$ Nesse caso, precisaria eu alterar o método?

Essas especulações só são, mais que exaustivas, úteis, na medida em que alertam para como a nossa conduta pode afetar o curso, a teoria, o método, o texto das nossas investigações. A violência de que somos vítimas não está separada dos dados; não é algo que posso simplesmente silenciar e tornar in- confessa, o que não significa dizer que seja uma fatalidade da qual não sairei ileso. Na condição de imerso, contudo, devo assumir, a depender do campo no qual me situo, que a violência compõe a atmosfera, o background seja da vida cotidiana dos nossos interlocutores, o que ficou claro nas narrativas, seja dos dados produzidos. No testemunho apresentado, ainda que em si mesmo profícuo em termos de

\footnotetext{
${ }^{15}$ Vale ressalvar que Donna Goldstein (2009) observou, na pesquisa que realizou com mulheres de uma favela carioca, que alguns detalhes sobre violência só eram compartilhados com ela fora da favela, de modo que era importante estar com suas interlocutoras em outros lugares da cidade.
} 
reflexão metodológica e ética, os dados de teor mais explicativo e significativo - para os propósitos do estudo - só emergiram após

a violência sofrida.

O caso nos convida a uma vez em trabalho de campo, nos concentrarmos e permitirmos ter a nossa sensibilidade aguçada ao lugar, no qual surgem outros que não são a princípio relevantes para a pesquisa e que, entretanto, devo levar em consideração - como o fazem outrossim as pessoas que acompanhamos. Isso apela para o próprio gerenciamento de impressões (SLUKA, 1990; SAMP-SON; THOMAS, 2003); lembremos que fazemos coisas que são também feitas por repórteres e espiões, como observar, perguntar, anotar, fotografar. Ao sermos surpreendidos com a existência e a força de outros atores ${ }^{16}$, muitas vezes não há, ao menos durante aquele momento em que estamos imersos enquanto pesquisadores, privilégios garantidos (NILAN, 2002), podendo encontrar justamente o contrário: vulnerabilidade advinda da condição de estrangeiros.

Caberia aqui nos perguntarmos se seria ético e honesto, na imersão em contextos de campo perigosos, não apenas acentuarmos as diferenças entre nós, jornalistas e policiais, como atenuá-las entre nós e "nativos" - Peritore (1990), por exemplo, sugere que compremos roupas e adiramos a corte de cabelos locais. Seria prudente que eu esclarecesse os traficantes sobre os propósitos da minha ida à festa? Também eles deveriam oferecer consentimento à minha pesquisa ${ }^{17}$ Bom, Bourgois (1990), que levanta algumas dessas questões no seu trabalho, responde que algumas vezes sentiu a necessidade de mentir a fim de proteger a si próprio, não achando sempre prudente ou prático representar-se com precisão para absolutamente todas as pessoas encontradas no campo. ${ }^{18}$

Logo percebemos uma solicitação de adotar, qual Rabelo (2016) no seu estudo sobre a ética no candomblé, em que deixa de pensá-la "como sistema abstrato e universal de valor morais" em favor de uma definição que a situe "enquanto um conjunto de problemas ou questões que confrontam qualquer campo de prática” (p. 111), uma ética mais localizada, maleável e menos rígida (BOURGOIS, 1990). Isto é, uma ética mais atenta às situações, "procurando nelas a chave para a boa conduta" (RABELO, 2016, p. 121). Viria ao nosso

\footnotetext{
${ }^{16}$ Pesquisadora de bairros periféricos desde o fim dos anos 80, em instigante debate sobre pobreza e criminalidade, publicado na íntegra na oitava edição da extinta revista Sexta-Feira, Vera Telles (2006) afirma que se antes acessava o campo com relativa facilidade, hoje não é possível prescindir da mediação de alguma liderança local. Como a tônica da sua comunicação recai sobre o novo cenário composto a partir da violência urbana, ela deixa tácito que - nas suas próprias palavras - esses "embaixadores" atuavam junto aos traficantes, no sentido de viabilizar a realização da pesquisa.

${ }^{17}$ Goldstein (2009) relata que fora persuadida por seus interlocutores a se apresentar ao chefe do tráfico local a fim de que não fosse confundida com alguém que não era, despertando, assim, certa confiança que qualquer suspeita de relação com a polícia fadaria ao fracasso.

${ }^{18}$ Por outro lado, Sluka (1990) argumenta que mais complicado que enganar pode ser ter a mentira descoberta depois. Como explicar as razões que lhe levaram a mentir?
} 
auxílio na composição deste contínuo exame do nosso agir o conhecimento local, capaz de reconfigurar a relação presente na ética convencional da disciplina entre antropólogo e colaborador de pesquisa (BOURGOIS, 1990).

Acautelar-se, portanto, consoante afirma Silva (2011) acerca da leitura deleuziana de Espinosa, "não significa seguir uma mera regra prática cujo uso pode ser generalizado a toda sorte de situação. Ter cautela é colocar-se numa atitude estratégica com os outros (...), é aprender a entrar em composição com eles”. Se seguir determinada orientação pode sugerir uma atitude de passividade, penso que tomar a prudência nos termos propostos implica precisamente o contrário: sustentar a agência do antropólogo. Este relato de como torneime vulnerável mostrou que foi justamente a imprudência que despojou-me de qualquer possibilidade de ação.

Se estivermos mesmo dispostos, enfim, a nos aventurarmos em campos perigosos, não podemos negligenciar a primordial importância dos nossos interlocutores de pesquisa para avaliar o espectro de riscos a que nos expomos no campo, para tecer uma cuidadosa consideração sobre a introdução de dispositivos de registro fotográfico (e outros), e para traçar estratégias que assegurem a realização da pesquisa e a esta sobreviver. Em poucas palavras: saber entrar e saber sair, transitar com segurança - o que sempre há de nos exigir, nunca é demais reforçar, um cuidado ético.

No final, resta ao pesquisador, e só a ele, decidir quão aceitáveis são os riscos a que poderá se expor (BOURGOIS, 1990; SLUKA, 1990).

\section{Referências bibliográficas}

BIONDI, Karina. Uma ética que é disciplina: formulações conceituais a partir do 'crime' paulista. Revista Fevereiro - Política, Teoria, Cultura, [s.1.], v. 10, p. 304-319, 2018.

BOURGOIS, Philippe. Confronting anthropological ethics: ethnographic lessons from Central America. Journal of Peace Research, London, v. 27, n. 1, p. 43-54, 1990.

CASTILLO, Lisa Earl. A fotografia e seus usos no candomblé da Bahia. Pontos de Interrogação, v. 3, n. 2, jul./dez. 2013. Disponível em: <https://www. revistas.uneb.br/ index.php/pontosdeint/article/view/1579/1040>. Acesso em: 10 out. 2015.

DELEUZE, Gilles; PARNET, Claire. Políticas. In: ___. Diálogos. Lisboa: Relógio D’Água, 2004. p. 151-176.

EMERSON, Robert M.; FRETZ, Rachel I.; SHAW, Linda L. Writing ethnographic fieldnotes. Chicago; London: The University of Chicago Press, 2011.

FAVRET-SAADA, Jeanne. Ser afetado. Cadernos de Campo, São Paulo, v. 13, n.13, p. 155$161,2005$.

FELTRAN, Gabriel de Santis. Trabalhadores e bandidos: categorias de nomeação, significados políticos. Temáticas, Campinas, v. 15, p. 11-50, 2007. Disponível em: 
<http://neip.info/novo/wp-content/uploads/ 2015/04/anexo--2-temticas.pdf>. Acesso em: 12 jun. 2015.

FONTES, Larissa Yelena Carvalho. A dádiva do segredo: a negociação do segredo ritual nas religiões afro-alagoanas. 2015. 122 f. Dissertação (Mestrado em Antropologia) Universidade Federal da Bahia, Salvador.

FRANÇA, Isadora Lins. Um mapa da pesquisa. In: Consumindo lugares, consumindo nos lugares: homossexualidade, consumo e subjetividades na cidade de São Paulo. Rio de Janeiro: EdUERJ, 2012. p. 25-73.

GAMA, Aline; PEIXOTO, Clarice. Identidades em movimento: uma etnografia em contexto de violência. Revista de Antropologia, São Paulo, v. 60, n. 3, p. 186-210, 2017.

GOLDMAN, Marcio. Alteridade e experiência: antropologia e teoria etnográfica. Etnográfica, Lisboa, v. 10, n. 1, p. 161-173, 2006.

GOLDSTEIN, Donna M. Perils of witnessing and ambivalence of writing: whiteness, sexuality, and violence in Rio de Janeiro shantytowns. In: HUGGINS, M. K.; GLEBBEEK, M-L. (Eds.). Women fielding danger: negotiating ethnographic identities in field research. New York: Rowman \& Littlefield, 2009. p. 227-249.

INGOLD, Tim. Chega de etnografia! A educação da atenção como propósito da antropologia. Educação, Porto Alegre, v. 39, n. 3, p. 404-11, set./dez. 2016.

JANSSON, André. Indispensable things: on mediatization, materiality, and space. In: LUNDBY, K. (Ed.). Mediatization of Communication. Berlin, Boston: Mouton de Gruyter, 2014. p. 273-295.

MARQUES, Adalton. Do ponto de vista do "crime": notas de um trabalho de campo com "ladrões”. Horizontes Antropológicos, Porto Alegre, ano 22, n. 45, p. 335-367, jan./jun. 2016.

MINTZ, Sidney W. Encontrando Taso, me descobrindo. Dados, Rio de Janeiro, v. 27, n. 1, p. 45-58, 1984.

NILAN, Pamela. 'Dangerous fieldwork' re-examinated: the question of re- searcher subject position. Qualitative Research, [s.1.], v. 2, n. 3, p. 363- 386, 2002.

OPIPARI, Carmen; TIMBERT, Sylvie. O artifício da imagem na construção do real. In: FERRAZ, A. L. C; MENDONÇA, J. M. de (Orgs.). Antropologia visual: perspectivas de ensino e pesquisa. Brasília: ABA, 2014. p. 371-406.

PERITORE, N. Patrick. Reflections on dangerous fieldwork. The American Sociologist, [s.1.], v. 21, n. 4, p. 359-372, dec. 1990.

PERLONGHER, Néstor. Antropologia das sociedades complexas: identidade e territorialidade, ou como estava vestida Margaret Mead. Revista Brasileira de Ciências Sociais, São Paulo, v. 8, n. 22, jun. 1993. 
RABELO, Miriam C. M. Aprender a ver no candomblé. Horizontes Antropológicos, Porto Alegre, ano 21, n. 44, p. 229-251, jul./dez. 2015.

Considerações sobre a ética no candomblé. Revista de Antropologia, São Paulo, v. 59, n. 2, p. 109-130, 2016.

ROCHA, Rosamaria Luiza de Melo. Uma cultura da violência na cidade? Rupturas, estetizações e reordenações. São Paulo em Perspectiva, São Paulo, v. 13, n. 3, p. 85-94, jul./set. 1999.

ROGERS-BROWN, Jennifer B. More than a war story: a feminist analysis of doing dangerous fieldwork. In: DEMOS, V.; SEGAL, M. T. (Eds.). At the center: feminism, social science and knowledge. London: Emerald, 2015. p. 111-31.

SAMPSON, Helen; THOMAS, Michelle. Lone researchers at sea: gender, risk and responsibility. Qualitative Research, [s.1.], v. 3, n. 2, p. 165-89, 2003.

SHARP, Gwen; KREMER, Emily. The safety dance: confronting harassment, intimidation, and violence in the field. Sociological Methodology, [s.1.], v. 36, p. 317-27, 2006.

SILVA, Cíntia Vieira da. Combater e compor: dilemas do agir em uma leitura deleuziana de Espinosa. Princípios, Natal, v. 19, p. 457-481, 2012.

SLUKA, Jeffrey A. Reflections on managing danger in fieldwork: dangerous anthropology in Belfast. In: ROBBEN, A. C. G. M.; SLUKA, J. A. (Eds.). Ethnographic fieldwork: an anthropological reader. Oxford: Blackwell, 2007. p. 259-68.

TELLES, Vera. Itinerários da pobreza e da violência. Sexta-Feira, São Paulo, n.8, p. 106-110, 2006.

VILLANI, Maycon Lopes. Para não ser uma bicha da favela: uma etnografia sobre corpo, sexualidade e distinção social. 2015. 146 f. Dissertação (Mestrado em Ciências Sociais) Universidade Federal da Bahia, Salvador.

ZALUAR, Alba. A máquina e a revolta: as organizações populares e o significado da pobreza. Rio de Janeiro: Brasiliense, 1985.

. Juventude violenta: processos, retrocessos e novos percursos. Dados, Rio de Janeiro, v. 55, n. 2, 2012, p. 327-65.

WACQUANT, Löic. Corpo e alma: notas etnográficas de um aprendiz de boxe. Rio de Janeiro: Relume Dumará, 2002.

\section{sobre o autor Maycon Lopes}

É bacharel, mestre e doutorando em Ciências Sociais pela Universidade Federal da Bahia, além de membro do Núcleo de Estudos em Ciências Sociais, Ambiente e Saúde (ECSAS). 